\title{
Modulation of Photosynthesis, Phenolic Contents, Antioxidant Activities, and Grain Yield of Two Barley Accessions Grown under Deficit Irrigation with Saline Water in an Arid Area of Tunisia
}

\author{
Mohamed Bagues ${ }^{1,2^{*}}$, Chokri Hafsi ${ }^{3}$, Yassine Yahia ${ }^{1}$, Ikbel Souli ${ }^{1}$, \\ Feiza Boussora ${ }^{1}$, Kamel Nagaz ${ }^{1}$ \\ ${ }^{1}$ Laboratoire d'Aridocultures et Cultures Oasiennes, Institut des Régions Arides, Médenine, Tunisie \\ ${ }^{2}$ Faculté des Sciences de Sfax, Sfax, Tunisie \\ ${ }^{3}$ Laboratoire des plantes Extrêmophiles, Centre de Biotechnologie de Borj-Cédria, Hammam-Lif, Tunisia
}

Received: 9 March 2018

Accepted: 3 July 2018

\begin{abstract}
The effects of irrigation with saline water were studied on barley plants cultivated under arid conditions at the Institute of Arid Regions located in the South East of Tunisia. Two barley accessions (Karkeni and Bengardeni) and three regimes of irrigation as a function of the cultural evapotranspiration ETc (T0: 100\% ETc, T1: 75\% ETc and T2: 50\% ETc) were used. Several parameters - gas exchange (A, E and gs), total flavonoid contents (TFC), total phenolic contents (TPC), phenolic compounds, antioxidant activity (DPPH and ABTS) and grain yield (GY) - were used to assess the effects of the studied factors on barley plants. Gas exchange parameters (A, E and gs) vary significantly between treatments. Salinity stress had no significant effect on TPC and TFC. Phenolic compounds varied significantly between treatments and accessions. In addition, their antioxidant activity based on DPPH and ABTS scavenging assays increased and are more important in Karkeni than Bengardeni under soil salinity. In addition, soil salinity decreased yield and yield components. Karkeni was more productive than Bengardeni.
\end{abstract}

Keywords: barley, gas exchange, drought-salinity, phenolic contents, antioxidant activity, grain yield

\section{Introduction}

In many regions of the world, drought and salinity are the two major abiotic factors affecting plant

*e-mail: bagues007@gmail.com

growth and productivity, particularly in irrigated areas in arid regions [1]. Besides, soil salinity is a major environmental stress that causes crop productivity losses worldwide. In addition to soils being naturally affected by salt, salinization due to anthropogenic factors, mainly insufficient irrigation and methods of tree deforestation, lead to ground and underground water [2]. In saline areas, crops that tolerate salinity are 
more productive than sensitive ones [3-4]. It is important to be able to grow salt-tolerant crops for reliable crop performance in salt soils, and from this point of view, it is necessary to develop salt-tolerant crops. Saline stress tolerance differs significantly between species [5-6]. Salt tolerance also differs between barley cultivars, rice and mung beans [4, 7-9]. The research works conducted to evaluate the combined effects of water and salt stresses on plants are scarce [10]. It was demonstrated that salt may partly mitigate the deleterious effects of drought on plant growth. [11-12] demonstrated that when simultaneously subjected to water-deficit stress and salinity, the halophyte Sesuvium portulacastrum displayed higher values of water and potassium use efficiencies, leaf proline and $\mathrm{Na}^{+}$concentrations associated with lower leaf water potential and an improvement of photosynthetic activity, suggesting the ability of this species to use $\mathrm{Na}^{+}$and proline for osmotic adjustment in comparison with plants subjected to each stress applied individually. However, the exact mechanisms of this beneficial effect of salt on plants grown under water deficit constraint are complex and require more study [13].

It is well known that salt stress provokes stomatal closure and consequently decreases $\mathrm{CO}_{2}$ fixation [14-16]. As a consequence, an over-reduction of photosynthetic electron chain can occur which stimulates the production of reactive oxygen species also known as ROS [17-18]. Those ROS are the leading cause of oxidative stress. Concretely, higher plants developed different protective mechanisms to reduce oxidative damage induced by salt stress. One of the major defense mechanism is the biosynthesis of especially efficient antioxidants such as phenolic compounds. In fact, polyphenols, including phenolic acids, flavonoids and proanthocyanidins, represent an important and powerful agent in scavenging free radicals [19-20]. Antioxidative capacities of phenolic compounds occur from their high reactivity as hydrogen or electron donors, from the particularity of the polyphenol-derived radical to stabilize and delocalize the unpaired electron, and from their capacities to chelate transition metal ions [21]. Furthermore, it has been shown in some recent studies that polyphenol biosynthesis is usually positively correlated to abiotic stress [22-16]. Particularly when plants were subjected to saline treatment, variations in antioxidant pools, notably in polyphenols, were found [16].

So, this research work aimed at investigating the effects of irrigation with saline water on two barley accessions cultivated in the field under arid environments in order to identify the tolerant accession under salt stress conditions and to understand the relationship between tolerance and productivity. Barley (Hordeum vulgare L.) is the fourth largest cereal crop in the world for foraging purposes and as a grain crop [23-24]. It also constitutes a genetic model for other crops [25].

\section{Materials and Methods}

\section{Plant Material and Growth Conditions}

The feedstock consisted of seeds and leaves belonging to "Ardhaoui," a local landrace of barley (Hordeum vulgare L.). Two specific accessions in southern Tunisia were studied: namely accession "Karkeni" from Karkenah and accession "Bengardeni" collected from Bengardene. The first one has been exploited for several years in irrigated crops at the Institute of Arid regions of Medenine, whereas the Bengardeni accession has been grown for a few years in fields and in rain fed by a small farmer in an arid region in order to compare their behavior when grown under deficit irrigation with saline water.

The experiment was conducted in the field at the Institute of Arid Regions, located at $22.5 \mathrm{~km}$ southeast of Medenine (10³8'30.34'E, 33'29'53.23'N alt $106 \mathrm{~m})$. The climate is Mediterranean, with hot and dry summers and mild winters, with an average annual rainfall of $125 \mathrm{~mm}$. Minimum temperatures recorded during November 2015 to May 2016, respectively, were between 3.5 and $15.7^{\circ} \mathrm{C}$, while maximum temperatures were between 16 and $39.8^{\circ} \mathrm{C}$ for the same period.

Crops were irrigated with a drip-irrigation system, three regimes were used as a function of the cultural evapotranspiration ETc (T0: $100 \%$ ETc, T1: 75\% ETc and T2: $50 \%$ ETc). The irrigation is done by a well of salinity varying between 4 to $7 \mathrm{~g} / \mathrm{l}$ during the experiment. The treatment $\mathrm{T} 0$ corresponds to the lowest soil salinity, the treatment $\mathrm{T} 2$ had the highest soil salinity, the soil is sandy soil. In addition to drought stress caused by the irrigation regimes, there was salt stress in the soil because of the absence of leaching. All parameters were measured at tillering stage.

\section{Gas Exchange Measurements}

Photosynthetic rate (A), stomatal conductance (gs) and transpiration were measured using a portable gas-exchange system (ADC BioScientific LC Pro+ System Serial No.3302). Gas exchange parameters were measured on the flag leaves. Leaf temperature was maintained at $25^{\circ} \mathrm{C}$, light intensity was set at $800 \mu \mathrm{mol}$ photons $\mathrm{m} / \mathrm{s}$ with a red/blue light source, and the $\mathrm{CO}_{2}$ concentration was set at $400 \mu \mathrm{mol} / \mathrm{mol}$. Leaf to air VPD was maintained at $1 \mathrm{KPa}$.

\section{Preparing Leaf Extract}

Several studies have shown that $80 \%$ methanol is an effective solvent in extracting phenolic and other polar substances from cereals [26]. In this study, 80\% methanol extracts from barley were used to determine total phenolic content and antioxidant property. Barley leaf samples $(200 \mathrm{mg})$ were extracted with $4 \mathrm{ml}$ acidified 
methanol $(\mathrm{HCl} / \mathrm{methanol} /$ water, 1:80:10, v/v/v) at room temperature $\left(25^{\circ} \mathrm{C}\right)$ for $2 \mathrm{~h}$ using an orbital shaker. The mixture was centrifuged at $3000 \mathrm{~g}$ for $10 \mathrm{~min}$. The supernatant was used for determining total phenolic content.

\section{Total Phenolic Content (TPC)}

Total phenolic content was determined by the Folin-Ciocalteu spectrophotometric method according to [27]. Total polyphenol contents were calculated as a gallic acid equivalent from the calibration curve of gallic acid standard solutions, and expressed as gallic acid equivalents (GAE) in milligrams per gram of dry plant material.

\section{Total Flavonoid Content (TFC)}

Total flavonoid content was determined by the method of aluminium trichloride using catechin as a reference compound [28]. Actually, $250 \mu \mathrm{L}$ of each extract (or catechin solution) is added to $1.25 \mathrm{~mL}$ of deionized water and subsequently mixed with an $\mathrm{NaNO}_{2}$ solution $(5 \%, 75 \mu \mathrm{L})$. The whole was allowed to stand for 6 min and $150 \mu \mathrm{L}$ of $10 \% \mathrm{AlCl}_{3}$ were added, as well as an $\mathrm{H}_{2} \mathrm{O}$ solution. As a final step, $0.5 \mathrm{~mL}$ of $1 \mathrm{M} \mathrm{NaOH}$ solution were added to the previous mixture incubated during $5 \mathrm{~min}$. Immediately, distilled water was added to bring a final volume to $2.5 \mathrm{~mL}$. The intensity of pink color was measured at $510 \mathrm{~nm}$. The TFC was interpreted as $\mathrm{mg}$ catechin equivalents (CE) /100 g of dry weight (DW).

\section{Analysis of Individual Phenolic Compounds by Analytical LC-ESI-MS}

Leaf methanolic extract was analyzed using an LCMS_2020 mass spectrometer (Shimadzu, Kyoto, Japan). LC system was equipped with an electrospray ionization source (ESI). Spectra were recorded in negative ion mode, monitored and processed using Shimadzu Lab Solutions LC-MS software. The LC20AD XR binary pump system, the SIL-20AC XR auto sampler, the CTO-20AC column oven and the DGU20AS degasser (Shimadzu, Kyoto, Japan) were the main elements of the LC system. For analysis, Thermo Electron (Dreieich, Germany) provided as with an Aquasil C18 column thermostatted at $40^{\circ} \mathrm{C}(150 \times 3 \mathrm{~mm}$, $3 \mu \mathrm{m})$ preceded by an Aquasil C18 guard column $(10 \times 3 \mathrm{~mm}, 3 \mu \mathrm{m})$. The used solvents were: A $(0.1 \%$ formic acid in $\left.\mathrm{H}_{2} \mathrm{O}, \mathrm{v} / \mathrm{v}\right)$ and $\mathrm{B}(0.1 \%$ formic acid in methanol, v/v). The elution gradient established was $10-100 \% \mathrm{~B}$ for $0-45 \mathrm{~min}, 100 \% \mathrm{~B}$ over $45-55 \mathrm{~min}$, and re-equilibration of the column lasted $5 \mathrm{~min}$ between individual runs. The flow rate of the mobile phase was $0.4 \mathrm{ml} \mathrm{min}-1$, and the injection volume was $5 \mu 1$. High-purity nitrogen served as the nebulizer and auxiliary gas. The ion spray voltage was set at $-3.5 \mathrm{v}$ in the negative mode. Settings used were: a nebulizing gas flow of $1.5 \mathrm{l} / \mathrm{min}$, a dry gas flow rate of $12 \mathrm{l} / \mathrm{min}$, a DL (dissolving line) temperature of $250^{\circ} \mathrm{C}$, a block source temperature of $400^{\circ} \mathrm{C}$ and a voltage detector of $1.2 \mathrm{v}$.

\section{Assessing Antioxidant Capacities}

\section{DPPH Radical-Scavenging Assay Determination}

This methodology was performed on leaves of barley according to the procedure described in [29]. The reaction mixture contained $1.5 \mathrm{ml}$ from a DPPH solution (4.73 mg of DPPH dissolved in $100 \mathrm{ml}$ Methanol HPLC-grade) and $100 \mu \mathrm{l}$ of methanolic leaf extract. The mixture was left to stand for $60 \mathrm{~min}$ in the dark. The reduction of the DPPH radical was determined by measuring the absorbance at $515 \mathrm{~nm}$. Trolox was used to develop standard curves. The radical-scavenging activity (RSA) was calculated as a percentage of inhibition as follows:

$$
\left.\% \text { inhibition }=\left[\left(\mathrm{A}_{\text {control }}-\mathrm{A}_{\text {sample }}\right) / \mathrm{A}_{\text {control }}\right)\right] \times 100
$$

\section{ABTS Radical-Scavenging Assay Determination}

The ABTS radical was carried out following the method of [30] with modifications. The $\mathrm{ABTS}^{-+}$was produced by reaction of $7 \mathrm{mM}$ stock solution of ABTS with $2.45 \mathrm{mM}$ potassium persulfate and allowing the mixture to stand in the dark at room temperature for 12-16 hours before use. Afterward, the solution was diluted and equilibrated to give an absorbance at $734 \mathrm{~nm}$ of $0.700 \pm 0.02$. Plant extracts $(120 \mu \mathrm{l})$ were allowed to react with $1.5 \mathrm{ml}$ of the diluted ABTS solution and the absorbance was read at 734 $\mathrm{nm}$ after $30 \mathrm{~min}$ of incubation. The ABTS radical inhibition was determined based on the following equation:

$$
\begin{gathered}
\% \text { inhibition }=\left[\left(\mathrm{A}_{\text {blank }}-\mathrm{A}_{\text {sample }}\right) / \mathrm{A}_{\text {blank }}\right] \times 100 \\
\text { Measurement of Yield and Yield Components }
\end{gathered}
$$

\section{Measurement of Yield and Yield Components}

Spike number per plant, grains number per spike and 1000-grain weight were counted at maturity stage. Grain yield was calculated using yield components $[\mathrm{GY}(\mathrm{g} / \mathrm{m})=$ grain number per spike $\mathrm{x}$ grain number per $\mathrm{m}^{2} \mathrm{x} 1000$ grains weight $\left.(\mathrm{g})\right]$ and expressed in $\mathrm{tha}^{-1}$.

\section{Statistical Analysis}

All data were analyzed by one-way ANOVA test, relationships between some parameters were determined using Pearson's simple correlation test, and means were compared using Duncan's test at $\mathrm{p}<0.05$ level of significance by means of SPSS 20 for Windows. 


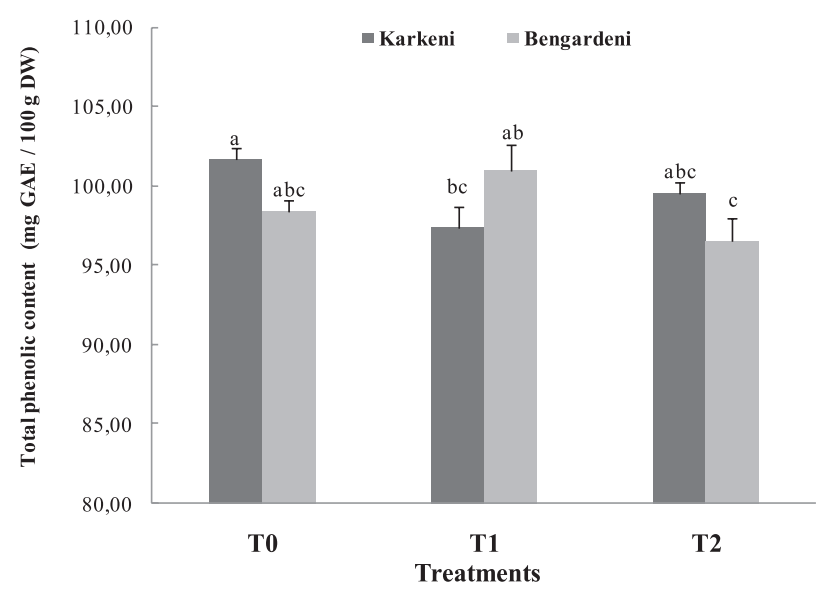

Fig. 1. Effect of deficit irrigation with saline water on total phenolic content (TPC) in flag leaves of the two barley accessions. Data are shown as means $\pm \operatorname{SE}(n=3)$. Values with different letters are significantly different at $\mathrm{p}<0.05$, according to Duncan's multiple range test.

\section{Results}

\section{Effect of Deficit Irrigation with Saline Water on Gas Exchange Parameters}

Salt treatment significantly decreased $\mathrm{CO}_{2}$ assimilation rate (A), transpiration rate (E), and stomatal conductance (gs). In Karkeni accession grown under T1 treatment, A, E, and $\mathrm{g}_{\mathrm{s}}$ were decreased by $30.7 \%$, $24.8 \%$, and $20 \%$, respectively. Under $\mathrm{T} 2$ treatment, these reductions were more pronounced $(71.8 \%$, $62 \%$, and $53.3 \%$, respectively for A, E, and $\mathrm{g}_{\mathrm{s}}$ ). For Bengardeni accession, the reductions were $22.5 \%$, $29.6 \%$, and $6.7 \%$ under $\mathrm{T} 1$ and $55.3 \%, 58.4 \%$, and $46.7 \%$ under T2, respectively, for A, E, and $g_{s}$. Generally, the Bengardeni accession maintained higher A compared to Karkeni accession. No significant differences were observed between the two accessions concerning $\mathrm{E}$ and $\mathrm{g}_{\mathrm{s}}$.

\section{Effect of Deficit Irrigation with Saline Water on Total Phenolic Contents}

The effects of irrigation treatments using saline water on total phenolic content (TPC) are shown in Fig. 1. According to this illustration, intially the two accessions exhibited statitically the same phenolic content (arround $96.7 \mathrm{mg} \mathrm{GAE} / 100 \mathrm{~g} \mathrm{DW}$ for control). Nevertheless, Bengardeni accession showed relatively higher TPC but was insignificant compared to Karkeni accession under stress conditions (T1). Interestingly, Table 2 data highlighted that TPC depends significantly on the accessions $(p<0.01)$, but not with salt treatment. No significant difference was observed on TFC between treatments and accessions.

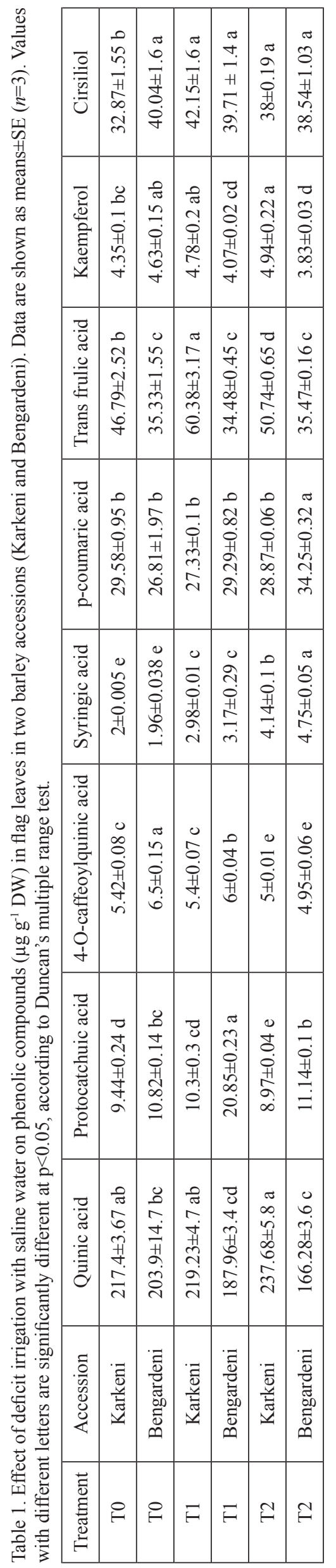


Table 2. Analysis of variance of total phenolic and flavonoid contents and antioxidant activities between accessions (Ac), treatments $(\mathrm{T})$ and their interaction $(\mathrm{T} \times \mathrm{Ac})$.

\begin{tabular}{|c|c|c|c|c|}
\hline Source of variance & TPC & TFC & DPPH & ABTS \\
\hline Treatment (T) & ns & ns & $* * *$ & $* * *$ \\
\hline Accession (Ac) & $* *$ & $\mathrm{~ns}$ & $* * *$ & $\mathrm{~ns}$ \\
\hline $\mathrm{T} \times \mathrm{Ac}$ & $\mathrm{ns}$ & $\mathrm{ns}$ & $* *$ & $* * *$ \\
\hline
\end{tabular}

$*$, **, *** significant at $\mathrm{p}<0.05, \mathrm{p}<0.01$ and $\mathrm{p}<0.001$, respectively; ns: non-significant

\section{Variation of Phenolic Compounds under Deficit Irrigation with Saline Water}

LC-ESI-MS analysis of phenolic compounds extracted from flags leaves two accessions under deficit irrigation with saline water is shown in (Table 1). Considering accession phenolic profiles, quantitative difference and qualitative similitude were observed. Qualitatively, eight phenolic compounds were detected in the two accessions: six phenolic acids (quinic, protocatechuic, 4-O-caffeoylquinic, syringic, p-coumaric and trans-ferulic acids) and two flavonoids (kaempferol and cirsiliol). Moreover, the major compounds were the same for Karkeni and Bengardeni accessions, with quinic acid content around $200 \mu \mathrm{g}$ $\mathrm{g}^{-1}$ DW followed by trans ferulic acid than cirsiliol. Quantitatively, phenolic contents varied statistically when comparing the two accessions. Actually, while quinic acid content reach $237 \mu \mathrm{g} \mathrm{g}^{-1}$ DW in Karkeni plants, it was limited to $20.3 \mu \mathrm{g} \mathrm{g}^{-1} \mathrm{DW}$ in Bengardeni ones (T2 treatment). The same tendency was also observed for trans-ferulic acid, syringic aid and kaempferol contents being higher in Karkeni accession. Regarding the treatment effect, Table 1 exhibited different phenolic behavior depending on treatment severity. In fact, quinic and 4-O-caffeoylquinic acids content decreased significantly as a function of treatment severity while protocatchuic, syringic and transferulic acid amounts showed statistical enhancment especially in Karkeni accessions. Taking syringic acid as an example, its content raised from 2 to $4.1 \mu \mathrm{g} \mathrm{g}^{-1}$ DW (Karkeni at T0 and T2, respectively) and from 2 to $4.7 \mu \mathrm{g} \mathrm{g}^{-1}$ DW (Bengardeni) at $\mathrm{T} 0$ and $\mathrm{T} 2$, respectively).

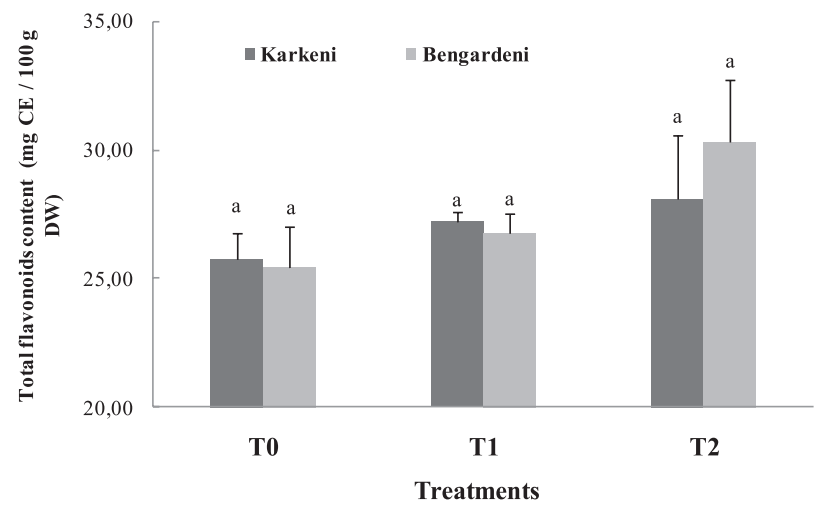

Fig. 2. Effect of deficit irrigation with saline water on total flavonoid content (TFC) in flag leaves of the two barley accessions. Data are shown as means $\pm \operatorname{SE}(n=3)$. Values with different letters are significantly different at $\mathrm{p}<0.05$, according to Duncan's multiple range test.

It is worth mentioning that analysis of variance resorted significant differences in phenolic compounds between treatments $(\mathrm{p}<0.01, \mathrm{p}<0.001)$ and accessions $(\mathrm{p}<0.001)$, except for syringic acid, $\mathrm{p}$-coumaric acid and cirsiliol (Table 3). As a matter of fact, the variations of all phenolic compounds under treatments depend on the response of each accession to drought and salinity. With this respect, trans-ferulic acid increases significantly, under treatments, with high values in Karkeni (until $60.4 \mu \mathrm{g} \mathrm{g}^{-1} \mathrm{DW}$ ), while it was significantly stable in Bengardeni (35.4 $\left.\mu \mathrm{g} \mathrm{g}^{-1} \mathrm{DW}\right)$.

\section{Effect of Deficit Irrigation with Saline Water on DPPH and ABTS Scavenging Assays}

The antioxidant activities in flag leaves of barley accessions were determined by DPPH and ABTS scavenging assays (Figs 3, 4), respectively. The DPPH values increased significantly between treatment and accession $(\mathrm{p}<0.001)$. Similarly, the ABTS values increased significantly between treatment, and there is significant difference between accessions. The DPPH and ABTS scavenging capacity were more pronounced in Karkeni than Bengardeni.

Table 3. Analysis of variance of phenolic compounds between accessions (Ac), treatments $(\mathrm{T})$ and their interaction (T x Ac).

\begin{tabular}{|c|c|c|c|c|c|c|c|c|}
\hline $\begin{array}{c}\text { Source of } \\
\text { variance }\end{array}$ & Quinic acid & $\begin{array}{c}\text { Protocatchuic } \\
\text { acid }\end{array}$ & $\begin{array}{c}4-\text { O-caffeoylquinic } \\
\text { acid }\end{array}$ & $\begin{array}{c}\text { Syringic } \\
\text { acid }\end{array}$ & $\begin{array}{c}\text { p-coumaric } \\
\text { acid }\end{array}$ & $\begin{array}{c}\text { Trans } \\
\text { frulic acid }\end{array}$ & Kaempferol & Cirsiliol \\
\hline Treatment (T) & $* * *$ & $* * *$ & $* *$ & $\mathrm{~ns}$ & $* *$ & $* * *$ & $* * *$ & $* * *$ \\
\hline $\begin{array}{c}\text { Accession } \\
\text { (Ac) }\end{array}$ & $* * *$ & $* * *$ & $* * *$ & $\mathrm{~ns}$ & $\mathrm{~ns}$ & $* * *$ & $* * *$ & $\mathrm{~ns}$ \\
\hline Tx Ac & $* * *$ & $* * *$ & $* * *$ & $* * *$ & $* * *$ & $* * *$ & $* * *$ & $* * *$ \\
\hline
\end{tabular}

$*, * *, * * *$ significant at $\mathrm{p}<0.05, \mathrm{p}<0.01$ and $\mathrm{p}<0.001$, respectively; ns: non-significant 


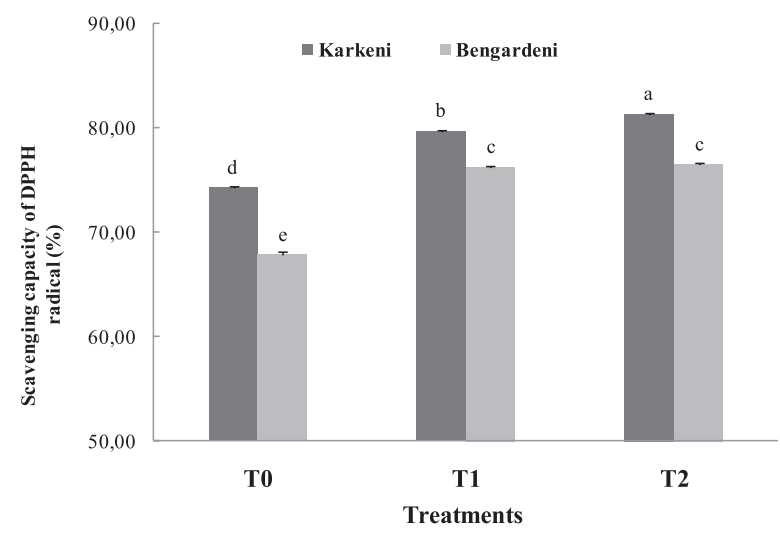

Fig. 3. Effects of deficit irrigation with saline water on antioxidant activities based on DPPH radical-scavenging assay in flag leaves of the two barley accessions. Data are shown as means $\pm \mathrm{SE}$ $(n=3)$. Values with different letters are significantly different at $\mathrm{p}<0.05$, according to Duncan's multiple range test.

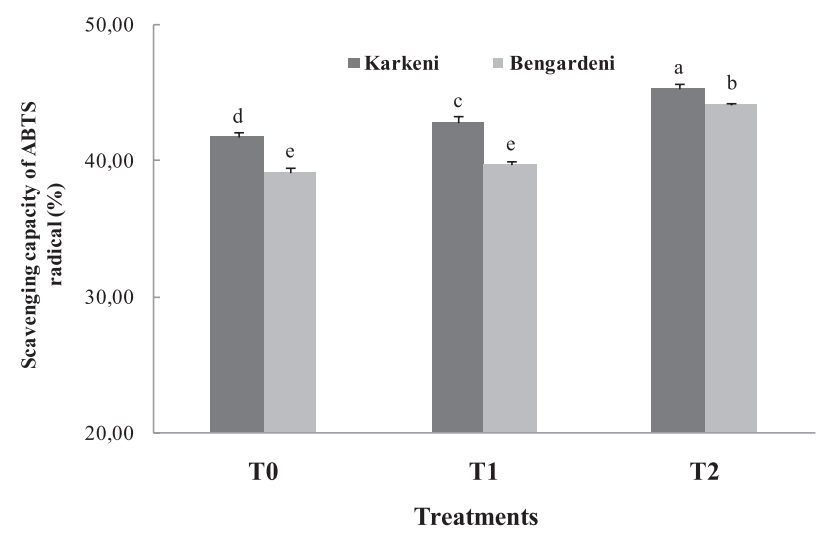

Fig. 4. Effects of deficit irrigation with saline water on antioxidant activities based on ABTS radical-scavenging assay in flag leaves of the two barley accessions. Data are shown as means \pm SE $(n=3)$. Values with different letters are significantly different at $\mathrm{p}<0.05$, according to Duncan's multiple range test.

\section{Effect of Deficit Irrigation with Saline Water on Yield and Yield Components}

The effects of deficit irrigation with saline water on yield and yield components are given in Table 4.
Drought and salinity at $\mathrm{T} 1$ and $\mathrm{T} 2$ levels caused a reduction in grain number per spike, spike number per plant, 1000 grain weight and grain yield. Between accessions, Duncan test showed a significant difference between Karkeni and Bengardeni under $\mathrm{T} 1$ and $\mathrm{T} 2$ levels in spike number per plant, 1000 grain weight and grain yield $(\mathrm{p}<0.05)$, no significant difference in grain number per spike (except at T1). Karkeni is more productive than the Bengardeni one.

\section{Discussion}

Drought and salinity, as well as numerous severe environmental conditions, hamper the vegetal metabolic systems in diverse ways. Since the dawn of time Hordeum vulgare has been considered a model plant in discerning the phenomenon of salinity tolerance. It is well documented that salt stress negatively affects plant growth and productivity as a consequence of decreased photosynthetic activity. Stomatal limitation (at intermediate salinity) and non-stomatal limitation (at biochemical level) under more severe saline conditions are responsible for the reduced photosynthetic capacity [31-14-16]. Salinity may limit the photosynthetic activity by a limitation of $\mathrm{CO}_{2}$ supply arising from the partial closure of stomata (stomatal function) or by altering the biochemical $\mathrm{CO}_{2}$ fixation mechanism (not stomatal function), or by both procedures [32].

Our results showed a significant decrease in photosynthetic parameters (A, E, and $g_{\mathrm{s}}$ ) following salt water treatments. Similar results were found by [33] in Nipponbare under different salinity regimes. The most decreases were observed in plants grown under T2 treatment. The reductions were more pronounced in Karkeni compared to Bengardeni (Figs 5-7). The decline in net photosynthesis (A) was more due to stomatal limitation in Karkeni than Bengardeni. These results corroborate those obtained by [34] in barley under salinity stress.

Phenolic compounds have been commonly associated with the detoxification of reactive oxygen species (ROS) displaying several important biological activities that alleviate oxidative stress [35]. According to the literature, salt-stressed barley produces intensive

Table 4. Means \pm SE $(n=6)$ of yield and yield components of barley accessions under irrigation treatments. Values with different letters are significantly different at $\mathrm{p}<0.05$, according to Duncan's multiple range test.

\begin{tabular}{|c|c|c|c|c|c|}
\hline Treatment & Accession & $\begin{array}{c}\text { Grain number } \\
\left(\text { spike }^{-1}\right)\end{array}$ & $\begin{array}{c}\text { Spike number } \\
\left(\text { plant }^{-1}\right)\end{array}$ & $\begin{array}{c}1000 \text {-grain weight } \\
(\mathrm{g})\end{array}$ & $\begin{array}{c}\text { Grain yield } \\
\left(\mathrm{t}^{-1}\right)\end{array}$ \\
\hline T0 & Karkeni & $50.66 \pm 1.15 \mathrm{a}$ & $7.66 \pm 0.57 \mathrm{a}$ & $46.94 \pm 0.41 \mathrm{a}$ & $3.121 \pm 0.24 \mathrm{a}$ \\
\hline T0 & Bengardeni & $48.66 \pm 1.15 \mathrm{a}$ & $7.33 \pm 0.57 \mathrm{ab}$ & $46.21 \pm 0.56 \mathrm{ab}$ & $2.4 \pm 0.76 \mathrm{~b}$ \\
\hline T1 & Karkeni & $48.66 \pm 3.05 \mathrm{a}$ & $6.33 \pm 0.57 \mathrm{abc}$ & $46.05 \pm 0.82 \mathrm{ab}$ & $2.164 \pm 4.1 \mathrm{bc}$ \\
\hline T1 & Bengardeni & $41.33 \pm 1.15 \mathrm{~b}$ & $6 \pm 1 \mathrm{bc}$ & $45.03 \pm 0.30 \mathrm{~b}$ & $1.861 \pm 1.82 \mathrm{~cd}$ \\
\hline T2 & Karkeni & $40.66 \pm 1.15 \mathrm{~b}$ & $6 \pm 1 \mathrm{bc}$ & $44.79 \pm 0.66 \mathrm{~b}$ & $1.651 \pm 0.51 \mathrm{~d}$ \\
\hline T2 & Bengardeni & $40.66 \pm 1.15 \mathrm{~b}$ & $5.66 \pm 0.57 \mathrm{c}$ & $39.45 \pm 1.29 \mathrm{c}$ & $1.250 \pm 0.27 \mathrm{e}$ \\
\hline
\end{tabular}




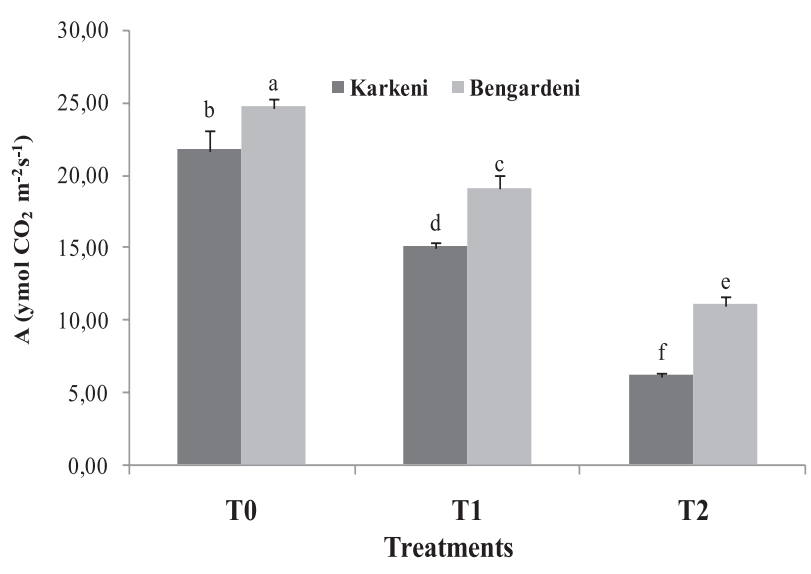

Fig. 5. Effect of deficit irrigation with saline water on photosynthetic rate (A) of the two barley accessions. Data are shown as means $\pm \operatorname{SE}(n=3)$. Values with different letters are significantly different at $\mathrm{p}<0.05$, according to Duncan's multiple range test.

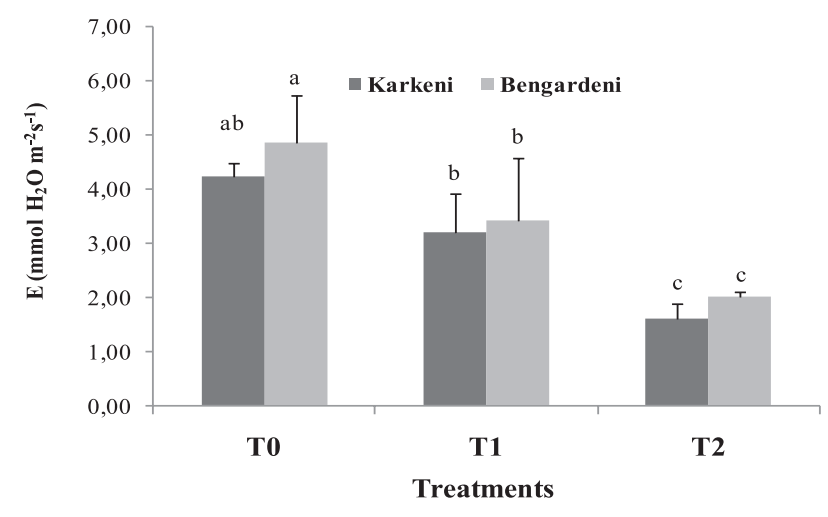

Fig. 6. Effect of deficit irrigation with saline water on transpiration (E) of the two barley accessions. Data are shown as means \pm SE $(n=3)$. Values with different letters are significantly different at $\mathrm{p}<0.05$, according to Duncan's multiple range test.

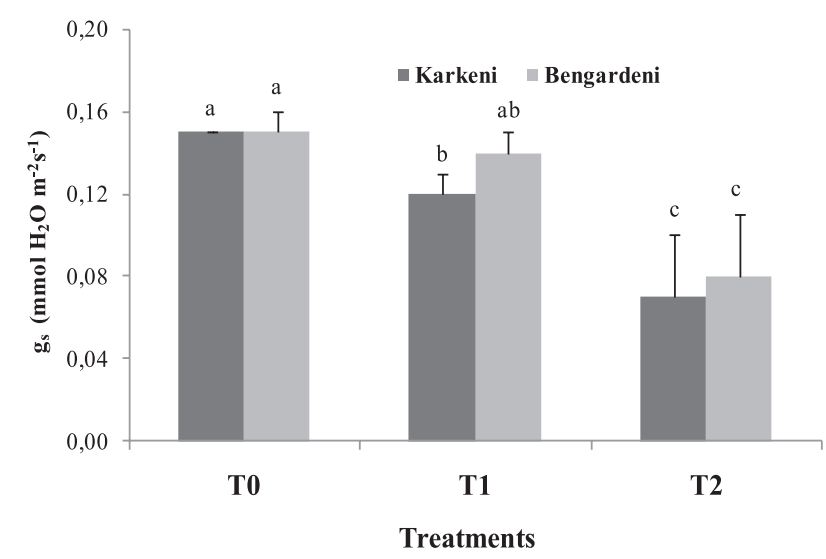

Fig. 7. Effect of deficit irrigation with saline water on stomatal conductance (gs) of the two barley accessions. Data are shown as means $\pm \mathrm{SE}(n=3)$. Values with different letters are significantly different at $\mathrm{p}<0.05$ according to Duncan's multiple range test. amounts of secondary metabolites, especially flavonoids and other phenolic components and thus mitigating the ionic repercussion of salt stress [36-37]. In our work, no significant difference was observed between treatments and accessions. In accordance with our results, [3738] found that salinity stress results in a reduction in TPC in Tibetan wild barley plants. Contrarily, [39] observed an increase in phenolic contents in rice under saline conditions. Quan et al. [40] and Minh et al. [41] observed an increase in TPC in rice plants grown under drought stress and salinity stress, respectively. Several other research works conducted on other species such as Cynara scolymus L., Hyssopus Officinalis L., Cichorium spinosum L. and Sulla carnosa showed an increase in total phenolic and flavonoid contents under saline conditions [16, 42-44].

Irrigation with saline water significantly affects phenolic compounds in the two barley accessions. In fact, p-coumaric acid increase in Bengardeni and decrease in Karkeni under saline conditions (Table 1), the high values of p-coumaric acid are found in Bengardeni than Karkeni. Eleuch et al [45] reported that p-coumaric acid increased under salinity stress for two barley cultivars (Acsad 1230 and Arig 8) and showed that the tolerant cultivar (Arig 8) has higher values of p-coumaric acid compared to sensitive cultivar (Acsad 1230) under severe salt stress (140 $\mathrm{mM}$ ). Recently, [41] reported that salt stress increases p-coumaric acid in rice. Also, [40] reported that p-coumaric acid increased under drought stress in rice. In another species, [46] showed that p-coumaric acid increased under saline treatments in cumin seeds. Kaempferol content increased in Bengardeni and decreased in Karkeni, 4-O-caffeoylquinic acid decreased in the two accessions. Our results are confirmed by [44] on Cichorium spinosum L. under saline stress. Protocatechuic acid also increased in most cases for the two accessions under irrigation with saline water [44]. Syringic acid increased under saline irrigation at the tillering stage. Similar results were found by [40] on rice under drought. Similar results were found by [46] in cumin under salt treatments. Quinic acid varies between accessions and salt irrigation levels. Quinic acid increased in Karkeni and decreased in Bengardeni accession. Our results are in agreement with those found by [47] on two contrasting wild barley genotypes under lower nitrogen stress. Quinic acid might improve the salt resistance of Karkeni, even at higher salt stress level (T2), because this metabolite was more accumulated in Karkeni accession than in the Bengardeni one with increasing salt stress. It can be concluded that the tolerance to salinity can be due to a modulation of phenolic compounds biosynthesis.

To evaluate the capacity of methanolic extracts of barley leaves, two tests were used (DPPH and ABTS). The irrigation with saline water increased antioxidant activities in the leaves of the two barley accessions. Our results were in agreement with those obtained by [39] on rice grains under salt stress. In contrast, 
Table 5. Correlation coefficients between total phenolic contents, antioxidant activities and grain yield.

\begin{tabular}{|c|c|c|c|c|c|}
\hline & TPC & TFC & DPPH & ABTS & GY \\
\hline TPC & 1 & $0.639^{* *}$ & $0.342^{*}$ & 0.125 & $-0.723^{* *}$ \\
\hline TFC & & 1 & $0.540^{* *}$ & 0.228 & $-0.851^{* *}$ \\
\hline DPPH & & & 1 & 0.017 & $-0.667^{*}$ \\
\hline ABTS & & & & 1 & $-0.567^{*}$ \\
\hline GY & & & & & 1 \\
\hline
\end{tabular}

*, ** significant at $P<0.05$ and $P<0.01$, respectively

an opposite behavior was found by [48] in wheat leaves under saline conditions. The highest DPPH and ABTS scavenging assays were observed at T1 and T2 treatments [49]. Karkeni showed higher DPPH and ABTS than Bengardeni in the same treatments. On two rice cultivars, the tolerant cultivar showed the lower $\mathrm{IC}_{50}$, that is to say, the high efficiency on scavenging DPPH [38]. These results agree with those found in our study. In fact, the antioxidant activity based on DPPH scavenging assay confirmed the TPC previously reported in our work, leading to a positive significant correlation between these parameters (Table 5). Similar correlations between DPPH scavenging assay and TPC have been reported in wheat leaves [48-50] and grain barley [51].

These differences in phenolic compounds and antioxidant activities of the two barley accessions under the irrigation with saline water will affect differently yield and yield components. In fact, salinity (T1 and T2) decreased grain number per spike, spike number per plant, 1000 grain weight and grain yield [39-52]. The study carried out by [3] showed that differences of cultivars in grain yield in barley increased with increasing soil salinity. Among accessions, it showed the high grain yield compared to Bengardeni as shown in Table 4.

\section{Conclusion}

We can conclude that the two barley accessions respond differently to deficit irrigation with saline water. Antioxidant activities increased and are more important in Karkeni than Bengardeni grown under saline conditions (T1 and T2). Photosynthetic activity is more important in Bengardeni than Karkeni in all treatments. On the other hand, Karkeni showed the high grain yield compared to Bengardeni.

\section{Acknowledgments}

We are grateful to Tebra Triki and Belgacem Lachiheb, two technicians in the Laboratory of Dry land and Oases Cropping of Institute of Arid Regions of Medenine.

\section{Conflict of Interest}

The authors declare no conflict of interest.

\section{References}

1. MOSTEK A., BORNER A., BADOWIEC A., WEIDNER S. Alterations in root proteome ofsalt-sensitive and tolerant barley lines under salt stress conditions. J Plant Physiol 174, 166, 2015.

2. PESSARAKLI M., SZABOLCS I. Handbook of Plant and Crop Stress, Soil Salinity and Sodicity as Particular Plant/ Crop Stress Factors. Third edition. CRC Press Taylor \& Francis Group, 6000 Broken Sound Parkway NW, Suite 300 Boca Raton, FL. 33487-2742. USA, 2011.

3. ROY S.J., NEGRAO S., TESTER M. Salt resistant crop plants. Current Opinion in Biotechnology 26, 115, 2014.

4. MACHADO R.M.A., SERRALHEIRO R.P. Soil Salinity: Effect on Vegetable Crop Growth. Management Practices to Prevent and Mitigate Soil Salinization. Horticulturae 3 (30), doi: 10.3390/horticulturae3020030, 2017.

5. SHAHBAZ M., ASHRAF M. Improving Salinity Tolerance in Cereals. Critical Reviews in Plant Sciences 32, 237, 2013.

6. NEGRAO S., SCHMOCKEL S.M., TESTER M. Evaluating physiological responses of plants to salinity stress. Ann Bot 119 (1), 1, 2017.

7. REDDY I.N.B.L., KIM B.K, YOON I.S., KIM K.H., KWON T.R. Salt Tolerance in Rice: Focus on Mechanisms and Approaches. Rice Science 24 (3), 123, 2017.

8. KATERJI N., VAN HOORN J.W., HAMDY A., MASTRORILLI M., C. FARES C., CECCARELLI S. GRANDO S., OWEIS T. Classification and salt tolerance analysis of barley varieties. Agricultural Water Management 85 (1), 184, 2006.

9. NAHAR K., HASANUZZAMAN M., RAHMAN A., MAHABUB ALAM M.D., AL MAHMUD J., SUZUKI T., FUJITA M.Polyamines Confer Salt Tolerance in Mung Bean (Vigna radiata L.) by Reducing Sodium Uptake, Improving Nutrient Homeostasis, Antioxidant Defense, and Methylglyoxal Detoxification Systems. Front. Plant Sci 28 July, doi.org/10.3389/fpls.2016.01104, 2016.

10. KHAN M.S.A., KARIM M.A., HAQUE M.M., ISLAM M.M., KARIM A.J.M.S., MIAN M.A.K. Influence of Salt and Water Stress on Growth and Yield of Soybean Genotypes. Pertanika J. Trop. Agric. Sci 39 (2), 167, 2016.

11. SLAMA I., GHNAYA T., HESSINI K., MESSEDI D., SAVOURE A., ABDELLY C. Comparative study of the effects of mannitol and PEG osmotic stress on growth and solute accumulation in Sesuvium portulacastrum. Environmental and Experimental Botany 61, 10, 2007.

12. SLAMA I., GHNAYA T., SAVOURE A., ABDELLY C. Combined effects of long-term salinity and soil drying on growth, water relations, nutrient status and proline accumulation of Sesuvium portulacastrum. C. R. Biologies 331, 442, 2008.

13. PANDEY P., IRULAPPAN V., BAGAVATHIANNAN M.V., SENTHIL-KUMAR M. Impact of Combined Abiotic and Biotic Stresses on Plant Growth and Avenues for Crop 
Improvement by Exploiting Physio-morphological Traits. Front. Plant Sci 8, 537, 2017.

14. CRUZ J.L., FILHO M.A.C., COELHO E.F., DOSSANTOS A.A. Salinity reduces carbon assimilation and the harvest index of cassava plants (Manihot esculenta Crantz). Acta Scientiarum. Agronomy, Maringá 39 (4), 545, 2017.

15. HUANG C., WEI G., JIE Y., WANG L., ZHOU H., RAN C., HUANG Z., JIA H., ANJUM S.A. Effects of concentrations of sodium chloride on photosynthesis, antioxidative enzymes, growth and fiber yield of hybrid ramie. Plant Physiol. Biochem 76, 86, 2014.

16. HAFSI C., FALLEH H., SAADA M., KSOURI R., ABDELLY C. Potassium deficiency alters growth, photosynthetic performance, secondary metabolites content, and related antioxidant capacity in Sulla carnosa grown under moderate salinity, Plant Physiology and Biochemistry. doi: 10.1016/j.plaphy.2017.08.002, 2017.

17. ROACH T., KRIEGER-LISZKAY A.K. Regulation of Photosynthetic Electron Transport and Photoinhibition. Curr Protein Pept Sci 15 (4), 351, 2014.

18. DAS K., ROYCHOUDHURY A. Reactive oxygen species (ROS) and response of antioxidants as ROS-scavengers during environmental stress in plants. Front. Environ. Sci., 02 December 2014, doi.org/10.3389/fenvs.2014.00053.

19. GEORGIEV V., ANANGA A., TSOLOVA V. Recent Advances and Uses of Grape Flavonoids as Nutraceuticals. Nutrients 6 (1), 391, 2014.

20. SKROVANKOVA S., SUMCZYNSKI D., MLCEK J., JURIKOVA T., SOCHOR J. Bioactive Compounds and Antioxidant Activity in Different Types of Berries. Int $\mathbf{J}$ Mol Sci 16 (10), 24673, 2015.

21. BHARTI K., PANDEY N., SHANKHDHAR D., SRIVASTAVA P.C., SHANKHDHAR S.C. Effect of different zinc levels on activity of superoxide dismutases $\&$ acid phosphatases and organic acid exudation on wheat genotypes. Physiol Mol Biol Plants 20 (1), 41, 2013.

22. HAFSI C., FALLEH H., SAADA M., RABHI M., MKADMINI K., KSOURI R., ABDELLY C., SMAOUI A. Effects of potassium supply on growth, gas exchange, phenolic composition, and related antioxidant properties in the forage legume Sulla carnosa. Flora 223, 38, 2016.

23. AL-KARAKI G.N. Germination, sodium, and potassium concentrations of barley seeds is influenced by salinity. $\mathrm{J}$ Plant Nutr 24, 511, 2001.

24. JIANG Q., ROCHE D., MONACO T.A., DUEHAM S. Gas exchange, chlorophyll fluorescence parameters and carbon isotope discrimination of fourteen barley genetic lines in response to salinity. Field Crops Research 96, 269, 2006.

25. ZHAO J., SUN H., DAI H., ZHANG G., WU F. Difference in response to drought stress among Tibet wild barley genotypes. Euphytica 172, 395, 2010.

26. ZIELINSKI H, KOZLOWSKA H. Antioxidant activity and total phenolic in selected cereal grains and their different morphological fractions. Journal of Agricultural and Food Chemistry 48, 2008, 2000.

27. PARAS S., HARDEEP S.G. Antioxidant and phenol oxidase activity of germinated barley and its milling fractions. Food Chemistry 120, 673, 2010.

28. ZHISHEN J.J., MENGCHENG T.T., JIANMIN W. The determination of flavonoid contents in mulberry and their scavenging effects on superoxide radicals. Food Chemistry 64, 555, 1999.

29. BRAND-WILLIAMS W., CUVELIER M.E., BERSET C. Use of free radical method to evaluate antioxidant activity. Lebensmittel-Wissenschaft und - Technology 28, 25, 1995.
30. RE R., PELLIGRINI N., PROTEGGENTE A., PANNALA A., YANG M., RICE-EVANS C.A. Antioxidant activity applying an improved ABTS radical cation decolorization assay. Free Radical Biology \& Medicine 26, 1231, 1999.

31. HAWORTH M., KILLI D., MATERASSI A., RASCHI A., CENTRITTO M. Impaired Stomatal Control Is Associated with Reduced Photosynthetic Physiology in Crop Species Grown at Elevated $\left(\mathrm{CO}_{2}\right)$. Front Plant Sci 7, 1568, 2016.

32. SENGUTTUVEL P., VIJAYALAKSHMI C., THIYAGARAJAN K., KANNANBAPU J.R., KOTA S., PADMAVATHI G., GEETHA S., SRITHARAN N., VIRAKTAMATH B.C. Changes in photosynthesis, chlorophyll fluorescence, gas exchange parameters and osmotic potential to salt stress during early seedling stage in rice (Oryza sativa L.). SABRAO Journal of Breeding and Genetics 46, 120, 2014.

33. ISHAK N.K., SULAIMAN Z., TENNAKOON K.U. Comparative study on growth performance of transgenic (Over-expressed OsNHX1) and wild-type Nipponbare under different salinity regimes. Rice Science 22, 275, 2015.

34. ALLEL D., BEN-AMMAR A., ABDELLY C. Leaf Photosynthesis, Chlorophyll Fluorescence and Ion Content of Barley (Hordeum vulgare L.) in Response to Salinity, Journal of Plant Nutrition, DOI: 10.1080/01904167.2017.1385811, 2017.

35. WANG Z., XU Y., WANG J., YANG J., ZHANG J. Polyamine and ethylene interactions in grain filling of superior and inferior spikelets of rice. Plant Growth Regul 66, 215, 2012.

36. PIASECKA A., SAWIKOWSKA A., KUCZYNSKA A., OGRODOWICZ P., MIKOLAJCZAK K., KRYSTKOWIAK K., GUDY K., GUZY-WROBELSKA J., KRAJEWSKI P., KACHLICKI P. Drought-related secondary metabolites of barley (Hordeum vulgare L.) leaves and their metabolomic quantitative trait loci. The Plant Journal 89, 898, 2017.

37. AHMED I.M., DAI H.X., ZHENG W., CAO F.B., ZHANG G.P., SUN D., WU F.B. Genotypic differences in physiological characteristics in the tolerance to drought and salinity combined stress between Tibetan wild and cultivated barley. Plant Physiol. Biochem 63, 49, 2013a.

38. AHMED I.M., NADIRA U.A., BIBI N., CAO F., HE X., ZHANG G., WU F. Secondary metabolism and antioxidants are involved in the tolerance to drought and salinity, separated and combined, in Tibetan wild barley. Environ Exp Bot 111, 1-12, 2015.

39. CHUNTHABUREE S., SANITCHON J., PATTANAGUL W., THEERAKULPISUT P. Effects of Salt Stress after Late Booting Stage on Yield and Antioxidant Capacity in Pigmented Rice Grains and Alleviation of the SaltInduced Yield Reduction by Exogenous Spermidine. Plant Production Science 18 (1), 32, 2015.

40. QUAN N.T., ANH L.H., KHANG D.T., TUYEN P.T., TOAN N.P., MINH T.N., MINH L.T., BACH D.T., HA P.T.T., EIZAAWELY A.A., KHANH T.D., TRUNG K.H., XUAN T.D. Involvement of Secondary Metabolites in Response to Drought Stress of Rice (Oryza sativa L.). Agriculture 6, 23, 2016.

41. MINH L.T., KHANG D.T., HA P.T.T., TUYEN P.T., MINH T.N., QUAN N.V., XUAN T.D. Effects of Salinity Stress on Growth and Phenolics of Rice (Oryza sativa L.). International Letters of Natural Sciences 57, 1, 2016.

42. REZAZADEH A., GHASEMZADEH A., BRANI M., TELMADARREHEI T. Effect of salinity on phenolic 
composition and antioxidant activity of Artichoke (Cynara scolymus L.) leaves. J. Med. Plant Res 6, 245, 2012.

43. JAHANTIGH O., NAJAFI F., BADI H.N., KHAVARINEJAD R.A., SANJARIAN F. Changes in antioxidant enzymes activities and proline, total phenol and anthocyanine contents in Hyssopus officinalis L. plants under salt stress. Acta Biologica Hungarica 67(2), 195, 2016.

44. PETROPOULOS S.A., LEVIZOU E., NTATSI G., FERNANDES A., PETROTOS K., AKOUMIANAKIS K., BARROS L., FERREIRA I.C.F.R. Salinity effect on nutritional value, chemical composition and bioactive compounds content of Cichorium spinosum L. Food Chemistry 214, 129, 2017.

45. ELEUCH L., REZGUI S., SLIM AMARA H. Effect of salt treatment on the expression of phenolics and peroxidase activity assessed in two barley cultivars Ascad 1230 and Arig 8. Journal of Agronomy 4 (3), 196, 2005.

46. BETTAIEB-REBEY I., BOURGOU S., RAHALI F.Z., MSAADA K., KSOURI R., MARZOUK B. Relation between salt tolerance and biochemical changes in cumin (Cuminum cyminum L.) seeds. Journal of Food and Drug Analysis 25, 391, 2017.

47. QUAN X., QIAN Q., YE Z., ZENG J., HAN Z., ZHANG G. Metabolic analysis of two contrasting wild barley genotypes grown hydroponically reveals adaptive strategies in response to low nitrogen stress. Journal of Plant Physiology 206, 59, 2016.
48. RAO A., AHMAD S.D., SABIR S.M., AWAN S., SHAH A.H., KHAN M.F., KHAN S.A., SHAFIQUE S., ARIF S., ABBAS S.R., GOHAR M. Antioxidant activity and lipid peroxidation of selected wheat cultivars under salt stress. Journal of Medicinal Plants Research 7 (4) 25, 155, 2013.

49. SUNIL D.K., JAI C.T., ACHARYA R., NILIMA S.R., DEVASAGAYAM T.P.A., REDDY A.V.R. Evaluation of antioxidant activity of wheat grass (Triticum aestivum L.,) as a function of growth under different conditions. Phytother. Res 20, 218, 2006.

50. TRUST B., SHIN N., JIM E.D., HARRY D.S. Antioxidant activity of pearled wheat and roller milled fractions. Cereal Chem 82, 390, 2005.

51. LAHOUAR L., EL AREM A., GHRAIRI F., CHAHDOURA H., BEN SALEM H., EL FELAH M., ACHOUR L. Phytochemical content and antioxidant properties of diverse varieties of whole barley (Hordeum vulgare L.) grown in Tunisia. Food Chemistry 145, 578, 2014.

52. HIRASAWA T., SATOA K., YAMAGUCHIA M., NARITAA R., KODAMAA A., ADACHIA S., OOKAWAA T., SATO K. Differences in dry matter production, grain production, and photosynthetic rate in barley cultivars under long-term salinity. Plant Production Science 20 (3), 288, 2017. 